\title{
Pavilion BIO-FADEN 1.0: Experimental study of design and manufacture with digital technologies of bionic prototype inspired by the fruit peels of fruit species present in the Central-Western Region of Brazil
}

\author{
Juan Carlos Guillen-Salas \\ University of Brasilia LFDC FAU I Brasil I arq_jcguisal@yahoo.com \\ Neander Furtado Silva \\ University of Brasilia LFDC FAU I Brasil I neander@unb.br \\ Luana Miranda Esper Kallas \\ Federal University of Goiás FAV I Brasil I luanakallas@ufg.br
}

\begin{abstract}
This article aims to determine the possibilities and limitations of the digital design and digital fabrication process by section or $2 \mathrm{D}$ laser cut in the production of artifacts composed of double curvature faces inspired by the non-euclidean geometric shapes of fruits present in the Central-Western Region of Brazil: Annona Cherimolal/Annona Squamosa., Mauritia Flexuosa, Annona Muricata, and the Annona Squamosa. Where, the main conclusion is that a set of digital techniques, parametric design and digital fabrication by section or 2D laser cutting can enable the production of a bionic pavilion, in a complex and cellular form in Brasília - DF.
\end{abstract}

Keywords: Bionics, Generative Design, Prototype, Digital Fabrication, Building Envelope.

\section{INTRODUCTION}

This article deals about the first experiment ( 3 years of experimentation) of a group of 7 experiments carried out in the doctoral thesis entitled "Design and Manufacture of Biomimetic Pavilion of Complex Form, Cellular and Responsive with Digital Technologies and Robotics in Brasilia - DF". Inside of the research project of "Parametric Modeling, Digital Fabrication and Mass Customization". Research line of "Production Technology of the Built Environment". "Technology, Environment and Sustainability" Concentration Area. Graduate Program of the Faculty of Architecture and Urbanism - PPGFAU - of the University of Brasilia - UnB - Campus Darcy Ribeiro. In the partnership of the Laboratory of Digital Fabrication and Mass Customization - LFDC/FAU/UnB - with the Faculty of Visual Arts - FAV - and the Laboratory of Materials and Manufacturing Processes of the Federal University of Goiás - LAMAF/EMC/UFG.

Where, this experimental study of design and manufacture with digital technologies of bionic prototype inspired by the fruit peels of fruit species present in the central-west region of Brazil is inserted in the context of the production of architectural envelopes inspired by nature. And, in which digital fabrication by section or $2 \mathrm{D}$ cut is little used in the production of structures of complex shapes, due to the few references about its possibilities and limitations.
In this sense, the problem of this research was to establish a set of methods and techniques that make feasible: the design, digital fabrication by section or $2 \mathrm{D}$ laser cut and, the construction of a bionic architectural envelope in a complex and cellular way in Brasília - DF.

The guiding hypothesis of the research was: It is believed that a set of digitization techniques, parametric design and digital fabrication by section or $2 \mathrm{D}$ laser cut can enable the construction of a complex and cellular bionic pavilion in Brasília - DF.

The main objective of this experiment was to determine the possibilities and limitations of the design, digital fabrication by section or $2 \mathrm{D}$ laser cut and the production of artifacts composed of double curvature faces. The artifacts were inspired by the non-Euclidean geometric shapes of the fruits of atemoia - Annona Cherimola, Mill and Annona Squamosa, L. (Santos et al., 2019, Cruz et al. 2013), buriti or Mauritia Flexuosa (Reis et al., 2017; Silva et al., 2014), soursop or Annona Muricata (Sacramento et al., 2003) and, the Pine cone or Count's fruit or Annona Squamosa (Santos, 2014).

The specific objectives were: 1) Determine the geometric characteristics of the fruit species; 2) Determine the importance of the rapid prototype of the double curvature surface (paper study model) for studying the geometry of fruit species. 3) Determine the importance of the threedimensional digitalization of the rapid prototype of the 
double curvature surface in the parametric definition; 4) Determine the importance of the parametric definition in the design process; 5) Determine the importance of the rapid $3 \mathrm{D}$ printing prototype (mockup printed in $3 \mathrm{D}$ by the process of deposition fused filament) in the planning and manufacture of the bionic pavilion of complex form on cardboard on $1: 1$ scale; 6 ) Determine the preparation stages for the process of making the bionic pavilion in a complex form using cardboard on 1:1 scale; 7) Determine the phases of the manufacturing process of the bionic pavilion of complex form in cardboard on 1:1 scale; 8) Determine the stages of assembling the bionic pavilion of complex form on cardboard on 1:1 scale.

The main limitation observed in the experiment is that the deformation of the final physical artifact is high in relation to the digital 3D model and/or physical 3D models produced by the digital fabrication process by addition. Among other limitations, such as: the greater use of logistics, the greater physical space for the manufacturing process and the longer period of time for manufacturing.

\section{METHODOLOGY}

The methodological process was structured in 3 stages: Fundamentals, Materials and, Design-FabricationAssembly.

\section{FUNDAMENTALS}

The fundamentals consisted of reviewing and systematizing the literature on: Bionics, Computer Numerical Control and Digital Fabrication.

\section{Bionic}

In the literature, most authors point out, to the American engineer, Jack Ellwood Steele as who formulated the term "bionics". At the same time, they point out that there is no consensus on when it was first used.

Most authors have a consensus on who formulated the term "bionics", but point out that there was another term that was used two decades earlier, in the same sense. Soares et al. (2016, p.1078), Pohl and Nachtigall (2015, p.1), Nachtigall and Pohl (2013, p.1), Gruber (2011, p.14, cited by Öztoprak, 2018, p.20), Nachtigall (cited by GRUBER, 2011, p.13), Acar (2011, p.9), Mahmoud (2010, p.1), Tübingen (2008, p.24) and Vincent (2006, p.471) pointed out that the The term "bionics" was coined by Jack Ellwood Steele. Gießler (cited by TÜBINGEN, 2008, p.24) used the term "biotechnik" in the same sense as the term "bionics" in 1939. Guillen Salas (2020, p.37) pointed out that the term "bionics" comes from "Biology" and "technology" and was coined by Jack Ellwood Steele in the mid-1950s.

At the same time, the authors have no consensus on the year in which the term "bionics" was coined. Soares et al. (2016, p.1078) pointed out that the term was used for the first time in 1958. Tübingen (2008, p.24) pointed out that the term was used in 1959. Vincent (2006, p.471) pointed out that the term was used in the year 1960.

Thus, with the majority of authors pointing out that Jack Ellwood Steele formulated the term "bionics" and that the authors do not agree on the year of appearance of the term; in such a situation, in this work, in agreement with Guillen Salas (2020, p.37), it will be adopted that the term "bionics" comes from "biology" and "technology" and was coined by Jack Ellwood Steele in the mid-1950s.

Regarding the definition of "Bionics", the authors point out that it is defined as the analysis of the forms of the nature to transfer them to technology.

Nachtigall (cited by Gruber, 2011, p.13) pointed out that in the english language the term comes from the combination of the words "biology", "technics" or "electronics" and, Tübingen (2008, p.24) pointed out that in the German language the term "bionik" is derived from the first three letters and the last three letters of the words "biologie" and "technik".

Jack Ellwood Stelee (cited by SOARES et. Al., 2016, p.1078) defined the term "bionics" as the analysis of the ways in which living systems act and have discovered the artifices of the nature. Gießler (cited by Tübingen, 2008, p.24) pointed out that "biotechnik" is the transfer from biology to technology. Guillen Salas (2020, p.39) defined "bionics" as the study of the forms of the nature to transfer them to technology.

Thus, since the authors indicate that the term "bionics" comes from the words "biology" and "technique" and that they define it as the analysis of the forms of the nature in order to transfer them to technology; in such a situation, in this work, in agreement with Guillen Salas (2020, p.39), the "bionics" will be adopted is the study of the forms of the nature to transfer them to technology.

\section{Computer Numerical Control - CNC}

The authors point out that the development of $\mathrm{CNC}$ technologies and computer aided design (CAD) contributed to the emergence of "Digital Fabrication" and the design of complex curve shapes.

Menges, Schwinn and Krieg (2017, p.XX) pointed out that the Massachusetts Institute of Technology (MIT) developed CNC in the 1950s. In the context in which CAD systems were also developed, as was the case with pioneering work by Ivan Sutherland, Sketchpad Tese, in 1963. The authors also indicated that in the same 1960s, complex curve modeling methods were developed in France by Paul Casteljau at Citroën and Pierre Bézier at Peugeot. This NURBS (non-uniform rational basis spline) modeling enabled the modeling of digitally curved surfaces.

Regarding the possibilities offered by NURBS modeling and Digital Fabrication, Estévez and Navarro (2016, p.1), in the article "From the electronic microscope to the digital strategy in architecture", they observed that, from the analysis in the electron microscope, it was possible to develop algorithms for 3D modeling and digital fabrication of a given artifact.

Caneparo (2014, p.56) pointed to the emergence of the CNC in 1956 as a result of the appearance of computers and the need to control machines by the United States Armed Forces. Guillen Salas (2002, p.56) sustained that "Digital Fabrication" emerged in the 1960s. 
Thus, the authors pointed out that CNC appeared in the 1950 s and that CAD technologies emerged in the 1960s; in such a situation, in this work, in agreement with Guillen Salas $(2020$, p.56), it will be adopted that "Digital Fabrication" emerged in the 1960s.

\section{Digital Fabrication}

The authors do not agree on the definition of "digital fabrication". But, they implicitly point out that it is a CNC manufacturing process of an object with customized material.

Wrangler et al. (2016, p.67) defined the digital fabrication as the application of digital modeling and manufacturing technologies for the production of customized material objects. Gershenfeld (2012, p.9) defined it as the process that uses computer-controlled tools that are descendants of the computer-controlled end mill at MIT in 1952. Gershenfeld pointed out that in the strictest sense of Digital Fabrication the same materials should be digital. Celani and Pupo (2010, p.1) defined it as the production of physical models and final objects directly from a computational modeling with numerically controlled machines. Iwamoto $(2009$, p.005) defined it as the way in which digital data controls manufacturing processes. Smith (cited by Kolarevic, Klinger, 2008, p.224) defined it as a machine-controlled manufacturing process. Smith also pointed out that in practice the digital manufacturing process tends to mix computer control with manual processes. Bonwetsch. et al. (2006, p.489) defined it as the manufacture of building components using CNC. Seely (2004, p.10) defined it as a computer-assisted process. Kolarevic (2003, p.1; 2001, p.2) defined it as the manufacturing process by machines with CNC. Guillen Salas (2020, p.57) defined "digital fabrication" as the CNC fabrication process of an object with a customized material. Where, CNC manufacturing can be understood as the preparation of a "digital file for the factory".

Thus some authors define it as a CNC manufacturing process, while others define it as machine-controlled manufacturing; in such a situation, in this work, in agreement with Guillen Salas (2020, p.57), it will be adopted that digital fabrication is a CNC fabrication process of an object with a customized material. Where, $\mathrm{CNC}$ manufacturing can be understood as the preparation of a "digital file for the factory".

Regarding the Digital Fabrication processes, the authors do not agree on the categories in which the processes are classified. But most mark 4 categories: Cut, Subtraction, Addition and Conformation..

Scopigno et al. (2015, p.2) marked 2 categories: Subtractive and Additive. Martins and Souza (2014, p.478) and Guzik (2009, p.15) divided the processes into 3 categories: Subtractive, Additive. Dunn (2012, p.88) marked 4 categories: Cut, Subtraction, Addition and Conformation. Kolarevic (2003, p. 52; 2001, p.2) presented 4 processes: Cutting, Subtraction, Addition and Conformation. Iwamoto (2009, p.004) presented 5 categories: Section, Tessellation, Bending, Contour, Conformation.
Thus, in this work, in agreement with Dunn and Kolarevic, it will be adopted that the digital manufacturing processes fall into 4 categories: Section, Subtraction, Addition and Conformation. Where: 1) The Cutting Process or 2D manufacturing, the most used process, consists of a cutting device and a cutting platform, where the cutting device moves in two axes ( $X$ and $Y$ ). 2) The Subtraction Process consists of removing a volume of material from a solid using multi-axis machining. 3) The Addition Process consists of forming a three-dimensional model in a layerby-layer casting process. E, 4) The Conformation Process consists of applying mechanical forces such as heat or steam to the material to give the desired shape by remodeling or deformation.

\section{MATERIALS}

The materials used in the experiment were classified into 8 categories: 1) Physical space: Room 31 at FAU / UnB; Room 8 at the Caraibas Classroom Center at UFG. 2) Furniture: $0.80 \mathrm{~m} \times 1.50 \mathrm{~m}$ tables; Chairs. 3) Equipment: Nikon DS600 model camera D600; Notebook SONY model VAIO, Processor Intel (R) Core (TM) i5-3210M CPU @ 2.50GHz 2.5 GHz, RAM 12 GB, 64-bit Operating System, Windows 8.1; Delta 3D printer; RepRap Uberblock printer; Laser cutter brand Thunder Laser, model Nova 51 , cutting table $1400 \mathrm{~mm} \times 1030 \mathrm{~mm}$; Laser Engraving \& Cutting Machine Laser Cutter, 1400mm x1030mm cutting table. 4) Software: Autodesk ReCap Pro; Rhinoceros 5.0; Grasshopper; Coreldraw 7.0; Thunder Laser; Lasercut 5.3. 5) Office Supplies: White Chamex paper, A4 format, $75 \mathrm{gr}$; Metal ruler; White glue; Paper adhesive tape; Fabric adhesive tape; Scissors; Stylus. 6) Carton Material: Simple wave cardboard of $1.40 \mathrm{~m} \times 1.00 \mathrm{~m}$; Plastic spatula; Screws, wing nuts, washers. 7) Construction Material: Safety glasses; Respirator for organic semi-facial vapors with 2 worker filters; Hydronorth water-based multipurpose resin; Wall brushes; Contact glue; Rubber sheet S / I blanket 4.5mm thick. 8) Transport: Private car; Moving truck.

\section{DESIGN-FABRICATION-ASSEMBLY}

This stage was structured in 8 phases:

1) Selection and photographic survey of fruit species. This phase was operationalized in 4 sub-phases:

Selection of fruit species. The fruit species were selected for their presence in the Midwest Region of Brazil and for the peculiarity of the geometric shapes on the outside of the fruits. The selected species were: atemoia, buriti, soursop and, pine cone or fruit of the count.

Photographic survey of fruit species. The fruits were photographed to analyze their geometric characteristics.

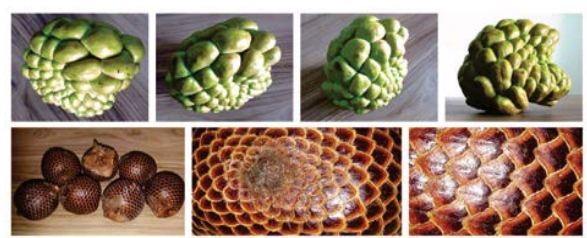




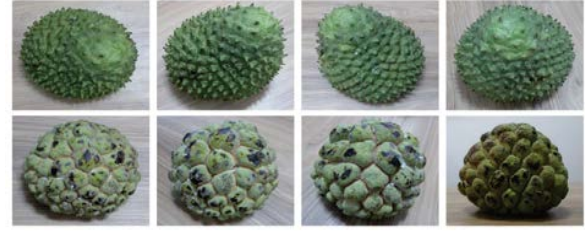

Figure 1: Photographic survey of Atemoia (row 1), Buriti (row 2), Soursop (row 3) and Pine cone or count fruit (row 4).

Scanning and photogrammetric rendering of species. The fruits were digitalized using the photogrammetric rendering technique (atemoia, soursop, pine cone) and definition of image contours (buriti).

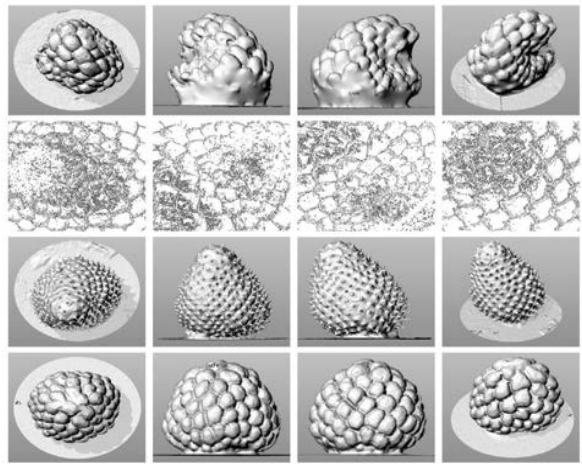

Figure 2: Digitization of fruits: atemoia (row 1), Buriti (row 2), Soursop (row 3) and Pine cone or count's fruit (row 4).

Three-dimensional representation of the module and surface. The three-dimensional representation was the result of the analysis of the modules, organization and variation in size and shape on the double-curvature surface.
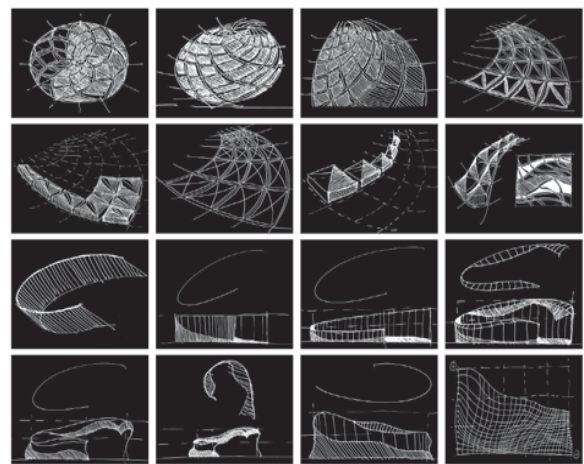

Figure 3: Analysis of the non-Euclidean geometries of the modules (rows 1 and 2) and the surface (rows 3 and 4 ).

2) Quick paper models for studying the geometry of double curved surfaces. This phase was operationalized in 3 sub-phases:

Quick double-curved surface paper mockup with regular shaped folds.

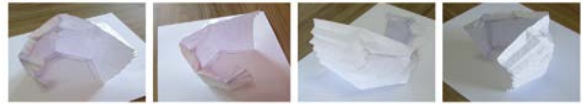

Figure 4: Quick paper mockup with regular shaped folds.

Quick double-curved surface paper mockup with irregularly shaped folds.
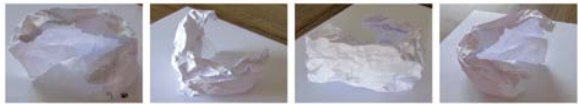

Figure 5: Quick paper mockup with irregularly shaped folds.

Quick paper mockups of modules built with regular shaped folds.
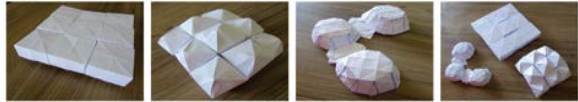

Figure 6: Module models with regular folds.

3) Photogrammetric survey and restitution of rapid paper models. This phase was operationalized in 2 sub-phases:

Photogrammetric restitution of the quick paper model of the double-curved surface with regular shaped folds:
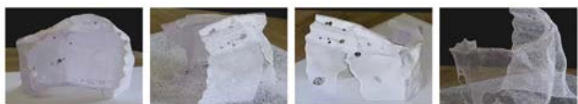

Figure 7: Restitution of the Rapid paper mockup of doublecurved surface with regular folds.

Photogrammetric restitution of the quick mockup of the double-curved paper surface with irregularly shaped folds.
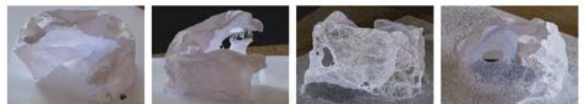

Figure 8: Quick paper model restitution of double curved surface with irregular folds.

4) Parameterization of the photogrammetric restitution of the rapid paper model of the double-curved surface with irregularly shaped folds. This phase was operationalized in 4 sub-phases:

Parameterization of irregularly shaped double curvature surface.
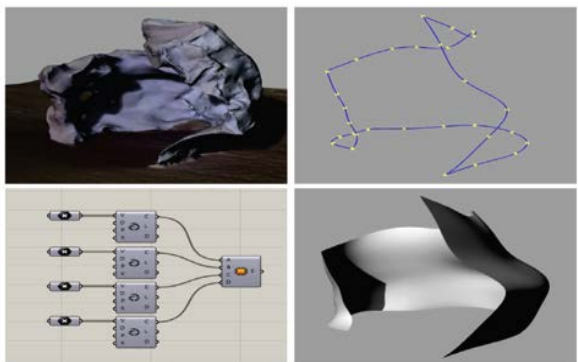

Figure 9: Parameterization of the double curvature surface. 
Double curvature surface paneling and module parameterization.

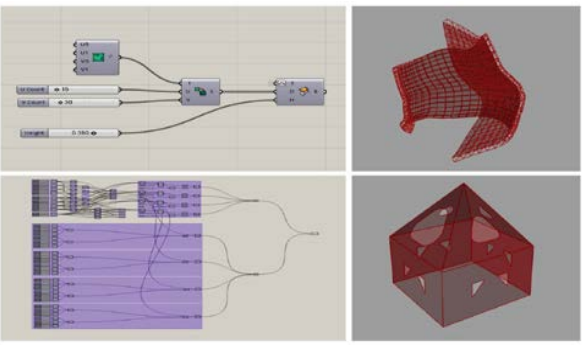

Figure 10: Double curvature surface paneling and module parameterization.

Parameterization of the prototype of the bionic pavilion in a complex form with modules prepared for digital fabrication by section and by addition.

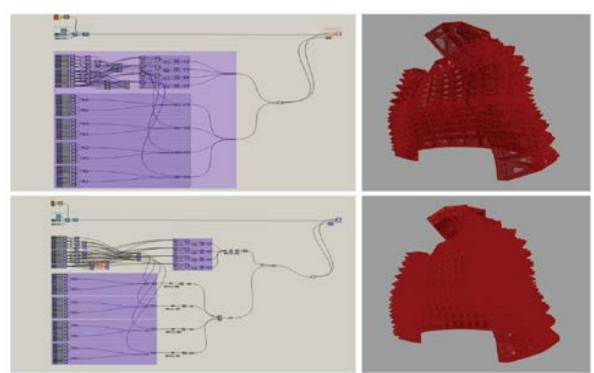

Figure 11: Parameterization of the prototype of the bionic pavilion for digital manufacturing by section and by addition.

Generation of prototypes of the bionic pavilion in a complex form with modules prepared for digital fabrication by section and addition.

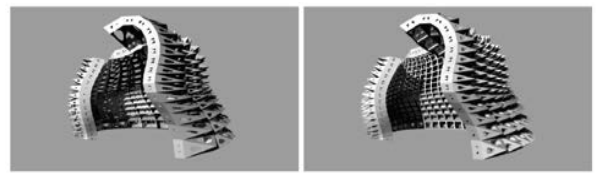

Figure 12: Generation of prototypes of the bionic pavilion.

5) Parameterization prototyping. This phase was operationalized in 2 sub-phases: Physical 3D prototypes of the parameters of the bionic pavilion for digital fabrication by section and by addition.
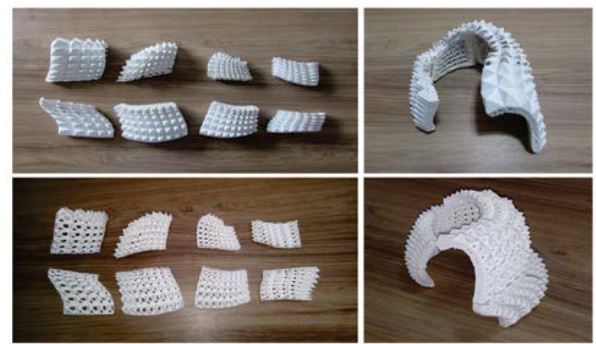

Figure 13: Physical 3D prototypes for manufacturing by section (left) and by addition (right).
6) Manufacturing process planning. This phase was operationalized in 3 sub-phases:

Preparation of the archives: Division of the bionic pavilion into panels.

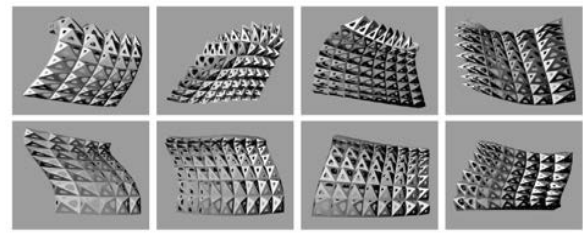

Figure 14: Division of the bionic pavilion into panels (panel 1, 3 , 5,7 in the upper row and panels $2,4,6,8$ in the lower row)

Material selection: single wave cardboard.

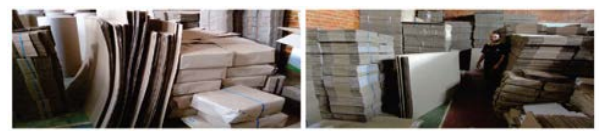

Figure 15: $6 \mathrm{~mm}$ single wave cardboard of $1.40 \mathrm{~m} \times 1.00 \mathrm{~m}$.

Editing files: Editing faces and lines for cutting and folding.

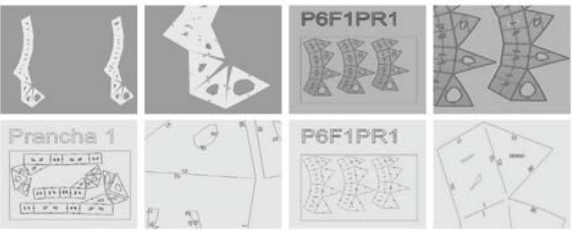

Figure 16: Edition of the faces (row 1) and edition of the lines (row 2).

7) Manufacturing. This phase was operationalized in 7 sub-phases:

Laser cutting of modules.
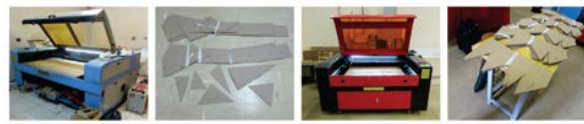

Figure 17: Laser cutting of modules in separated parts and in one piece.

Module assemblies and panels organization:
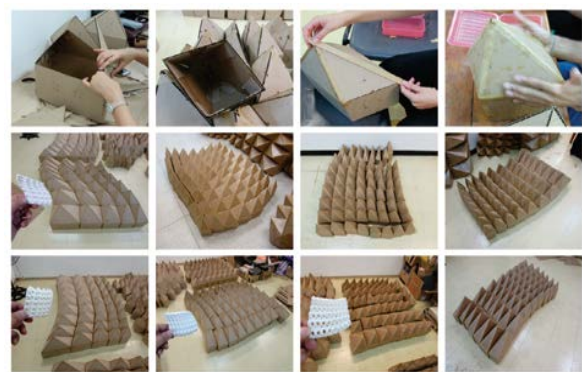

Figure 18: Assembly of modules (row 1) and presentation of panels (rows 2 and 3 ). 
Assembly of the panels:

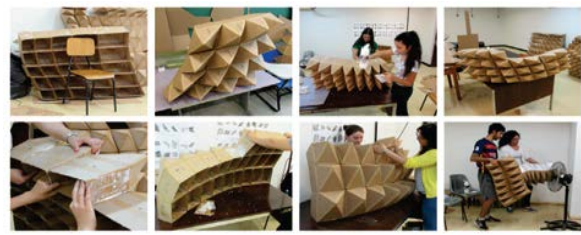

Figure 19: Assembly of the panels.

Presentation of the assembled panels.

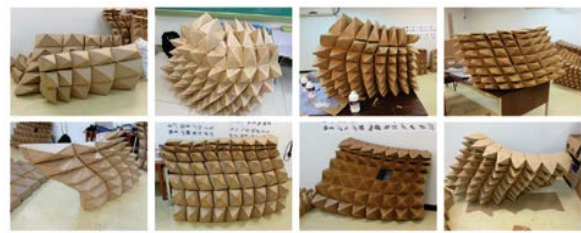

Figure 20: Presentation of the assembled panels.

Comparison of the reduced size panels manufactured by addition to the panels constructed with cardboard in the 1 : 1 scale.
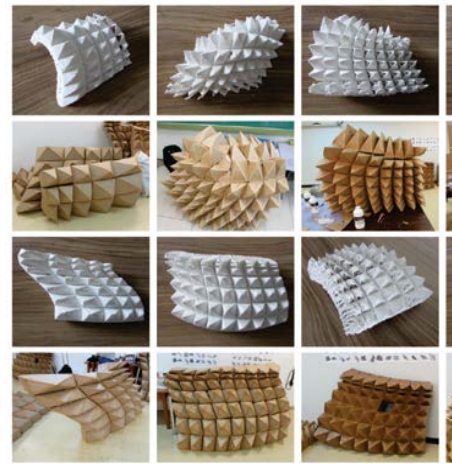

Figure 21: Comparison of the small size panels manufactured by addition and the panels constructed with cardboard in the 1:1 scale.

Waterproofing panels made of cardboard.

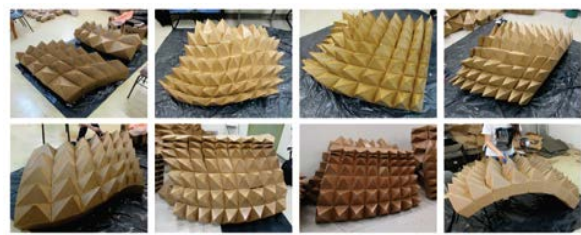

Figure 22: Water-based resin application on panels made with cardboard.

Protection of the base of panels with rubber.

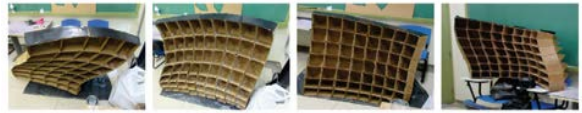

Figure 23: Rubbering of the panels (panels 2, 4, 6, 8).

8) Assembly of the pavilion. This phase was operationalized in 3 sub-phases:

Manufacture of devices for fixing panels.

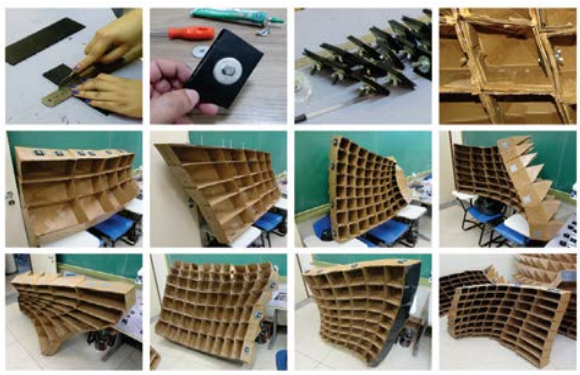

Figure 24: Devices for fixing panels.

Pavilion construction:

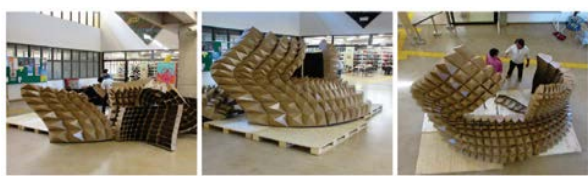

Figure 25: Assembly of the bionic pavilion.

Comparison of the pavilion with the small size prototypes.

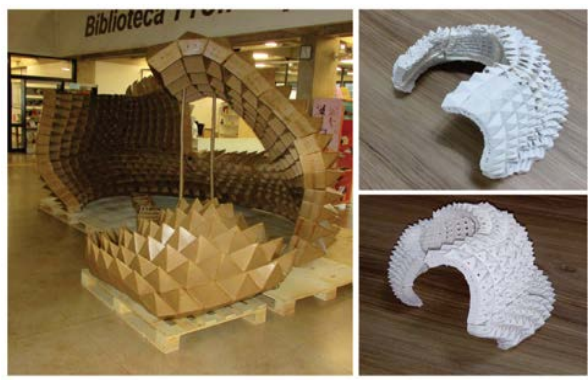

Figure 26: Comparison of the Pavilion with the small size prototypes.

\section{RESULTS}

The fruit species were selected for their presence in the Midwest Region of Brazil and for the non-Euclidean geometric peculiarity of their fruits. The modules of the fruit peels modify their size and shape according to the curvatures of the surface that conform.

Rapid paper models with irregularly shaped folds (crumpled paper) present a greater possibility in defining double-curved surface shapes, but modules built with regular shaped folds (squares and triangles) presented a possibility to define double curvature surfaces. 
The parameterized prototypes of the bionic pavilion in a complex form were prepared considering digital manufacturing strategies and end use.

The physical 3D prototyping of the bionic pavilion in small size - to be produced by the digital fabrication process by section in the 1:1 scale or by the digital fabrication process in small size - is necessary for the study of the final form, of the planning of the manufacturing, the manufacturing process itself, and the assembly of the pavilion.

The bionic pavilion with dimensions of $2.5 \mathrm{~m} \times 2.5 \mathrm{~m} \times 2.5 \mathrm{~m}$ was divided into 8 panels to make its manufacture with simple $6 \mathrm{~mm}$ thick cardboard on boards of $1.40 \mathrm{~m} \times 1.20 \mathrm{~m}$. Cardboard was chosen for its low cost and availability in the local stationery market. The digital files for laser cutting needed two editing phases: editing of the split and organization of the modules and editing for definition of the cut lines and the folding lines.

The manufacture of modules and cloths is a manual production process that presents limitations in terms of matching the produced artifact and the digital model. The modules and panels showed a reduction in resistance due to the size variation.

The pavilion can be manufactured hybridly (mixing digital manufacturing processes and manual manufacturing processes) using simple wave cardboard. Making sure that the surface curvatures are smooth and the size of the modules is related to the strength of the cardboard. Considering that the hybrid manufacturing process presents greater deformation than the digital manufacturing process by addition.

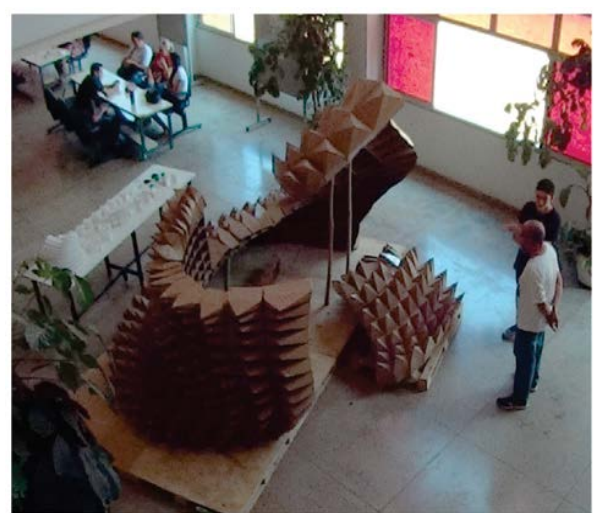

Figura 27: Exhibition of the Pavilion BIO-FADEN 1.0 in the Faculty of Letters/UFG.

\section{DISCUSSION}

The areas with marked double curvatures generated failures in the manufacture and assembly of the pavilion and modules. These failures can be predicted at the time of design and at the stage of the first edition of the modules in the digital environment.

The deformation of the bionic pavilion can be reduced and the resistance can be increased using smaller size modules. This was observed in panels made up of smaller modules, which showed less deformation and greater resistance.

The use of light and malleable material requires the implementation of a support structure for the bionic pavilion. This was observed in the exhibition periods of the pavilion, where over time the lower modules undergo deformation due to pressure from the upper modules.

\section{CONCLUSION}

The guiding hypothesis of the experiment was confirmed. A set of digitization techniques, parametric design and digital fabrication by section or 2D laser cut can enable the production of a bionic pavilion, in a complex form and cellular in Brasília - DF. However, to use digital fabrication by section or $2 \mathrm{D}$ cut it is necessary to take into account the physical characteristics of the artifact to be produced and the characteristics of flexibility and resistance of the material to be used in the production. As noted by GuillénSalas and Silva (2021, p.154).

The main limitation observed in digital fabrication by section was the deformation of the final product in relation to the 3D digital models and physical 3D models produced by the addition process with fused filament deposition.

\section{ACKNOWLEDGMENTS}

CAPES and DPG/UnB.

LFDC / FAU, Warehouse / UnB, Prof. Ecilamar Macie Lima, Ma. Leonardo Barreto. FAU/UnB students: Adriana C. Pereira, Alexandre Alves, Aline Biu, Emily V. U. Pellegrin, Júlia Nascimento, Leonardo Figueiredo, Lucas Ber, Jéssica Ferreira, Luiz F. Machado, Mario S. Facundes Taveira and Pedro Braga.

FAV/UFG, LAMAF/EMC/UFG, FL/UFG, Central Library/UFG, Sectional Library/UFG, Prof. Dr. Luana Miranda Esper Kallas, Prof. Dr. Israel Elias Trindade, Prof. Dr. Braulio Vinícius Ferreira, Prof. Dr. Daniel Fernandes da Cunha, Prof. Alexandre de Araújo Badim, Techn. João Bosco da Cunha, Librarian Adriana Ribeiro, Librarian Márcia Calil. FAV/UFG students, Júnior da Silva Mata, Livia Aracelli Rocha Abreu, Gracielly Fonseca Cordeiro.

Luiz, Rosa Harumi, Fabiana, Fredy Ugarte.

\section{REFERENCES}

Acar, M. S. (2011) Bio-inspired design of a kinetic node for adaptable structures. 132 p. Dissertation (Master of Science in Architecture) - Department of Architecture, Graduate School of Engineering and Sciences, İzmir Institute of Technology, Urla, İmir, Turkey.

Bonwetsch, T. et al. (2006) The Informed Wall. applying additive digital fabrication techniques on architecture. In: ACADIA, p. 489-495.

Caneparo, L. (2014) Digital Fabrication in Architecture, Engineering and Construction. Springer Science+Business Media Dordrecht: New York, London.

Celani, G.; Duarte, J.; Pupo, R. (2010) Introducing digital fabrication laboratories in architecture schools. Planning and operating. Retrieved from 
http://www.fec.unicamp.br/ lapac/papers/celani-duarte-pupo2010.pdf. Access in: 04 nov. 2017.

Cruz, L. S. da et al. Caracterização física e química das frações do fruto atemoia Gefner. Ciência Rural, Santa Maria, 2013. v.43, n.12, p.2280-2284, dez. Retrieved from http://www.scielo.br/pdf/cr/v43n12/a33713cr2012-0439.pdf. Access in: 31 may 2019.

Dunn, N. (2012) Digital fabrication in architecture. Laurence King Publishing: London. $192 \mathrm{p}$.

Estévez, A. T.; Navarro, D. (2016) Del microscopio electrónico a la estrategia digital en arquitectura. In: SIGraDi, p. 734742.9-11, November, - Buenos Aires, Argentina

Gershenfeld, N. (2012) How to Make Almost Anything.The Digital Fabrication Revolution. Foreign Affairs. Volume 91, No. 6.

Gruber, P. (2011).Biomimetics in architecture: Architecture of life and buildings. Springer-Verlag/Wien. Retrieved from file://C:/Users/JnKrlos.VAIO/Downloads/Gruber-2011-

Biomimeticsinarchitecturearchitectureoflifeandbuildings $\% 20$ (1 ).pdf. Access in: 14 jun. 2017.

Guillén-Salas, J. C.; Silva, N. F. (2021) Digital Fabrication Experimentations with Complex Form Modular Bionic Building Envelope with 3D Printing and Robotics Technology. In: H. RODRIGUES, et al. (eds) Sustainability and Automation in Smart Constructions, Advances in Science, Technology \& Innovation. Springer Nature Switzerland AG 2021. p. 143-155. https://doi.org/10.1007/978-3-030-35533318

Guillen Salas, J. C. (2020) Projetação e Fabricação de Pavilhão Biomimético de Forma Complexa, Celular e Responsivo com Tecnologias Digitais e Robótica em Brasília - DF. 377 f. Tese (Doutorado em Arquitetura e Urbanismo) - Programa de Pós-Graduação de Arquitetura e Urbansimo, Universidade de Brasília, Brasília - DF, Brasil.

Guzik, A. (2009) Digital fabrication inspired design: Influence of fabrication parameters on a design process. $71 \mathrm{p}$. Dissertation (Master of Science in Adaptive Architecture and Computation) - Bartlett School of Graduate Studies, University College of London, London, UK.

Iwamoto, L. (2009) Digital fabrications. Architectural and material techniques. Princeton Architectural Press: New York, United States of America. $144 \mathrm{p}$.

Kolarevic, B.; Klinger, K. R. (eds.) (2008) Manufacturing material effects: Rethinking design and making in architecture. Routledge is an imprint of the Taylor \& Francis Group, an informa business: New York, United States of America. 321 p.

Kolarevic, B. (ed.) (2003) Architecture in the digital age. design and manufacturing. Spon Press is an imprint of the Taylor \& Francis Group.

Kolarevic, B. (2001) Digital Fabrication: Manufacturing Architecture in the Information Age. In: ACADIA, 2001, Suny Buffalo, Proceedings... Buffalo, New York, United States of America. Section 4, p. 268-278.

Mahmoud, E. (2010) Biomimicry: A New Approach to Enhance the Efficiency of Natural Ventilation Systems in Hot Climate. In: International Seminar Arquitectonics Network, Architecture and Research, Barcelona, Spain. Proceedings... Barcelona, 2010. 2 Retrieved from https://pdfs.semanticscholar.org/204b/2efe8f55ff439e1586be 90a6ca0c6a5d9193.pdf?_ga=2.51571309.514357249.15784 50818-1536409723.1546030185. Access in: 5 may 2017.

Martins, P. F.; Sousa, J. P. (2014) Digital fabrication technology in concrete architecture. In: ECAADE, p. 475-484.

Menges, A.; Schwinn, T.; Krieg, O. D. (2017) Advancing wood architecture. A computational approach. Routledge Taylor \& Francis Group. London, New York. 259 p.

Nachtigall, W.; Pohl, G. (2013) Bau-Bionik. Natur - Analogien Technik. Springer-Verlag Berlin Heidelberg,
Öztoprak, Z. A (2018) Biomimetic perspective on (retro)fitting of building envelopes. 200 p. Tese (Doctor of Philosophy) Architecture, Graduate School of Natural and Applied Sciences, Middle East Technical University, Çankaya, Ankara, Turkey. Retrieved from http://etd.lib.metu.edu.tr/upload/12621923/index.pdf. Access in: 17 jul. 2019.

Pohl, G.; Nachtigall, W. (2015) Biomimetics for architecture \& design. Springer International Publishing. Switzerland.

Reis, S. B.; Mello, A. C. M. P.; oliveira, D. M. T. (2017) Pericarp formation in early divergent species of Arecaceae (Calamoideae, Mauritiinae) and its ecological and phylogenetic importance. Plant Syst Evol 303:675-687. DOI 10.1007/s00606-017-1399-6. Retrieved from https://linkspringer-

com.ez54.periodicos.capes.gov.br/content/pdf/10.1007\%2Fs 00606-017-1399-6.pdf. Access in: 31 may 2019.

Sacramento, C. K. do et al. (2003) Caracterização física e química de frutos de três tipos de gravioleira (Annona muricata L.). Rev. Bras. Frutic., Jaboticabal - SP, v. 25, n. 2, p. 329-331, Agosto Disponível em: https://www.scielo.br/pdf/rbf/v25n2/a37v25n2.pdf. Acesso em: 31 maio 2019 .

Santos, R. C. dos et al. (2019) Atemoya fruit development and cyto-logical aspects of GA3-induced growth and parthenocarpy. Protoplasma. Retrieved from https://doi.org/10.1007/s00709-019-01382-2. Access in: 31 may 2019.

Santos, R. C. dos et al. (2014) Stenospermy and seed development in the "Brazilian seedless" variety of sugar apple (Annona squamosa). Anais da Acade-mia Brasileira de Ciências 86(4): 2101-2108. Retrieved from http://dx.doi.org/10.1590/0001-3765201420140206. Access in: 31 may 2019

Scopigno, R. et al. (2015) Digital fabrication techniques for cultural heritage: A survey. In: COMPUTER GRAPHICS Forum. p. 1-17.

Seely, J. C. K. (2004) Digital fabrication in the architectural design process. 77 p. Dissertation (Master of Science in Architecture Studies) - Massachusetts Institute of Technology, Massachusetts, Boston, United States of America.

Silva, R. S et al. (2014) Seed structure and germination in buriti (Mauritia flexuosa), the Swamp palm. Flora - Morphology, Distribution, Functional Ecology of Plants, Volume 209, Issue 11, November. Pages 674-685. Retrieved from https://doi.org/10.1016/j.flora.2014.08.012. Access in: 31 may 2019.

Soares, T. L. de F. et al. (2016) Princípios Analógicos da Biomimética e sua aplicação nos Domus Geodésicos de Fuller. Retrieved from http://dx.doi.org/10.4995/IFDP.2016.3369. Access in: 27 may 2019

Tübingen, D. H. B. aus. (2008) Bionisch inspirierte Gebäudehüllen. Konzeption einer Bionisch inspirierter Gebäudehülle nach dem Vorbild natürlicher Hüllen und Häute. 474 p. Tese (Doktor-Ingenieurs) - Fakultät Architektur und Stadtplanung, Universität Stuttgart. Stuttgart, BadenWürttemberg, Deuschland.

Vincent, J. F. V. et al. (2006) Biomimetics: its practice and theory. J. R. Soc. Interface 3, 471-482. Retrieved from https://www.researchgate.net/publication/6937083_Biomimeti cs_Its_Practice_and_Theory. Access in: 4 nov. $20 \overline{17}$.

Wrangler, T. et al. (2016) Digital concrete: opportunities and challenges. RILEM Technical Letters 1: 67 - 75, ISSN 25180231, DOI 10.21809/rilemtechlett.2016.16 